\title{
PENERAPAN SOFTWARE GEOGEBRA DALAM MATERI SEGITIGA DAN SEGIEMPAT DALAM MENINGKATKAN KEMAMPUAN KOMUNIKASI MATEMATIK SISWA SMP
}

\author{
M. Diki Fadilah', Gagan Aditya Fauzan², Wahyu Setiawan ${ }^{3}$ \\ 1,2,3 IKIP Siliwangi Cimahi \\ 1dikyfadillah53@gmail.com² gaganaditya197@gmail.com,3 setiawan@stkipsiliwangi.ac.id
}

\begin{abstract}
This study aims to determine the effect of GeoGebra software on junior high school students' mathematical communication skills. The method used is the quasi-experimental method. This research was conducted at Pasundan Rongga Middle School. With class VIII A as an experimental class with 28 students and class VIII C as a control class with 28 students. This study uses instruments that have been tested and declared valid and reliable. The instrument was adjusted to the indicator of mathematical communication skills with the number of questions tested as many as 5 questions to obtain pretest and posttest data in both the experimental class and the control class. Data testing is done using normalized n-gain formula so that the n-gain data obtained is processed using the SPSS 20 application to perform parametric statistical tests. The results showed that the mathematical communication skills of students who learned using GeoGebra software were better than students who learned without using GeoGebra software.
\end{abstract}

Keywords: GeoGebra software, mathematical communication skills of students, middle school students

\begin{abstract}
Abstrak
Penelitian ini bertujuan untuk mengetahui pengaruh software GeoGebra terhadap kemampuan komunikasi matematik siswa SMP. Metode yang digunakan yaitu metode kuasi eksperimen. Penelitian ini dilakukan di SMP Pasundan Rongga. Dengan kelas VIII A sebagai kelas eksperimen dengan jumlah 28 siswa dan kelas VIII C sebagai kelas kontrol dengan jumlah 28 siswa. Penelitian ini menggunakan instrumen yang telah diujicoba dan dinyatakan valid dan reliabel. Instrumen disesuaikan dengan indkator kemampuan komunikasi matematik dengan jumlah soal yang diujicobakan sebanyak 5 soal untuk memperoleh data pretes dan postes baik kelas eksperimen maupun kelas kontrol. Pengujian data dilakukan dengan menggunakan rumus $n$-gain ternormalisasi sehingga memperoleh data $n$-gain yang diolah meggunakan aplikasi SPSS 20 untuk melakukan uji statistika parametrik. Hasil penelitian menunjukan bahwa kemampuan komunikasi matematik siswa yang pembelajarannya menggunakan software GeoGebra lebih baik daripada siswa yang pembelajarannya tanpa menggunakan software GeoGebra.
\end{abstract}

Kata Kunci: software GeoGebra, Kemampuan komunikasi matematik siswa, Siswa SMP

How to cite: Fadilah, MD., Fauzan, GA., \& Setiawan, W. (2019). Penerapan Softrware GeoGebra dalam Materi Segitiga dan Segiempat untuk Meningkatkan Kemampuan Komunikasi Matematik Siswa SMP. JPMI - Jurnal Pembelajaran Matematika Inovatif, 2 (6), 385-392. 


\section{PENDAHULUAN}

Pada penelitian yang dilakukan oleh penulis di SMP Pasundan Rongga,berbagai macam hal telah penulis temukan di SMP Pasundan Rongga, dimulai dari karakteristik siswa yang heterogen, dari segi fasilitas, lingkungan pendidikan, tenaga pengajar, prestasi, sarana dan prasarana di SMP Pasundan Rongga yang menurut penulis masih sangat kurang. Hal ini berdampak kepada rendahnya kemampuan siswa dalam mengikuti pembelajaran di sekolah khususnya pembelajaran matematika. Dimana siswa masih kesulitan dalam mengetahui simbol, memaparkan data dan grafik kedalam bentuk deskriptif, memahami suatu gambar, serta memahami soal cerita dalam pembelajaran matematika. Hal ini dikarenakan beberapa faktor, antara lain dari faktor siswa dan lingkungan sekitar. Dimana lingkungan sekitar membentuk minat belajar siswa terhadap pembelajaran matematika cenderung rendah, siswa cenderung lebih berminat terhadap pelajaran yang berkaitan erat dengan kebudayaan. Faktor lain yang mempengaruhi adalah peran guru. Dimana beberapa guru di SMP Pasundan Rongga masih cenderung paling aktif dalam kegiatan pembelajaran sehingga siswa cenderung pasif dalam mengkomunikasikan pemahamannya dalam pembelajaran. Guru juga kurang menggunakan teknologi dalam pembelajaran sehingga pembelajaran cenderung menjenuhkan dan kurang menarik sehingga timbulah masalah rendahnya kemampuan komunikasi matematik siswa dalam pembelajaran.

Komunikasi merupakan hal yang sangat penting dalam kehidupan. Dalam KBBI komunikasi artinya pengiriman dan penerimaan pesan, atau berita antara dua orang atau lebih sehingga pesan yang dimaksud bisa dipahami. Begitupun dalam pembelajaran matematika komunikasi merupakan hal yang sangat penting, sehingga dikenalah kemampuan kognitif dalam pembelajaran matematika yaitu kemampuan komunikasi matematik. Menurut Asikin (2001) kemampuan komunikasi matematik merupakan suatu dialog antara atau hubungan anatara guru dan murid dalam suatu kelas, sehingga terjaadi pengalihan pesan. Dengan komunikasi siswa dapat menyampaikan pemikiran, ide, gagasan, dan inisiatif dalam pembelajaran. Selain itu dengan komunikasi siswa dapat menyampaikan mengenai kesulitan - kesulitan dalam pembelajaran kepada guru, sehingga guru dapat memberikan umpan balik mengenai kesulitan yang dialami oleh siswa. Kemampuan komunikasi matematik merupakan kemampuan untuk memahami dari suatu konsep materi matematika. Hal ini sama dengan apa yang diungkapkan oleh Isaneni \& Ripi Maya (2014) bahwa kemampuan komunikasi matematik berperan sebagai representasi pemahaman siswa terhadap konsep pembelajaran matematika matupun bidang pembelajaran lainnya.

Kemampuan komunikasi matematik merupakan dasar dari seluruh kemampuan kognitif dalam pembelajaran matematik. Hal ini diperkuat oleh pernyataan Ismarwan (2013) bahwa kemampuan komunikasi matematik merupakan dasar kemampuan matematis yang esensial dan harus dimiliki oleh siswa dalam pembelajaran. Karena tanpa kemampuan komunikasi matematik yang baik siswa akan kesulitan untuk menjabarkan data, tabel, membuat pola, membuat model matematika, memahami soal cerita, simbol matematik, grafik, dan konsep konsep matematika. Kemampuan tersebutlah yang dapat menunjuang terbentuknya kemampuan berpikir kritis, logis, sistematis, dan bekerjasama dengan efektif. Hal tersebut akan membentuk cara berpikir matematika yang tersruktur dan memiliki keterkaitan konsep yang kuat dan jelas dan dapat membentuk siswa yang terampil berpikir secara rasional (Depdiknas, 2003). Sehingga tujuan pembelajaran matematika Kurikulum 2013 (Kemendikbud, 2013) dapat tercapai, yaitu pembelajaran yang lebih menekankan pada dimensi pedagogik modern. Komunikasi matematik juga dapat dipakai sebagai tolak ukur kemampuan siswa dalam mengikuti kegiatan pembelajaran selama satu semester. Sehingga dapat digunakan sebagai 
bahan evaluasi dan penilaian pembelajaran bagi peserta didik. Hal ini sama dengan Permendikbud (2013) bahwa sebuah pendidikan tidak hanya mementingkan hasil akan tetapi proses dalam pembelajaran. Maka dari itulah dalam Kurikulum 2013 penilaian terbagi kedalam tiga aspek dengan porsi yang sama yaitu aspek kognitif, afektif, dan psikomotor. Selain itu dalam setiap pertemuan guru memberikan penilaian terhadap aktivitas yang dilakukan siswa dalam pembelajaran. Aktivitas tersebut dikatakan baik jika siswa dapat mengkomunikasikan setiap ide, gagasan, dan kesulitan yang ditemukan dalam pembelajaran. Adapun indikator yang terdapat dalam kemampuan komunikasi matematik menurut NCTM (2000) antara lain: (1) menyusun pemikiran matematis melalui komunikasi; (2) mengkomunikasikan pemikiran secara logis dan jelas; (3) menganalisis serta mengevaluasi pemikiran matematis dan strategi dalam pembelajaran; (4) menggunakan bahasa matematis untuk menyampaikan ide dengan tepat.

Dalam Kurikulum 2013 selain kemampuan komunikasi matematik. Pemanfaatan teknologi sangat diperlukan dalam pembelajaran di sekolah yang telah menggunakan kurikulum 2013, dimana pada kurikulum 2013 ini guru dan siswa dituntut untuk dapat menggunakan teknologi. Pembelajaran dengan bantuan teknologi sangat baik untuk diintegrasikan dalam pembelajaran konsep-konsep matematika. Hal ini sejalan dengan apa yang diungkapkan oleh Ngurah Japa (2017) bahwa dengan adanya TIK dapat memberikan nuansa baru dalam kegatan pembelajaran. Matematika merupakan pelajaran dasar yang harus dikuasai siswa dimana pelajaran tersebut berkaitan langsung dengan kehidupan sehari-hari baik dalam jual beli, perniagaan, jam, alat transaksi dan lainnya. Selain itu matematika merupakan ilmu yang mendukung dan berperan aktif dalam perkembangan Ilmu Pengetahuan Teknologi (IPTEK). Berbagai program komputer telah banyak dikembangkan untuk menunjang pembelajaran yang efektif dan inovatif, salah satunya adalah software GeoGebra. Menurut Hohenwarter (2008) GeoGebra adalah program dengan beragam fasilitasnya dapat dimanfaatkan sebagai media pembelajaran matematika untuk mendemonstrasikan atau memvisualisasikan konsep-konsep matematis serta sebagai alat bantu untuk mengkonstruksi konsep-konsep matematis. Dengan software GeoGebra siswa dapat memami konsep matematika dimanapun dan kapanpun. Hal ini serupa dengan yang diungkapkan oleh Munir (2010) bahwa software GeoGebra merupakan implementasi pembelajaran yang menggunakan teknologi dan tidak terbatas ruang dan waktu.

Berdasarkan permasalahan dan pemaparan mengenai pentingnya kemampuan komunikasi matematika serta peranan teknologi dalam pembelajaran matematika. Penulis tergerak untuk melakukan penelitian di SMP Pasundan Rongga untuk mengetahui seberapa signifikan pengaruh software GeoGebra terhadap kemampuan komunikasi matematik dalam pembelajaran.

\section{METODE}

Penelitian ini dilakukan di SMP Pasundan Rongga dengan populasi penelitian adalah seluruh siswa kelas VIII SMP Pasundan Rongga Kabupaten Bandung TA 2018/2019. Metode yang digunakan ialah metode kuasi eksperimen. Dengan sampel penelitian adalah kelas VIII A dan kelas VIII C dimana pengambilan sampel ini berdasarkan purposive sampling. Dengan kelas VIII A sebagai kelas eksperimen dengan jumlah 28 siswa dan kelas VIII C sebagai kelas kontrol dengan jumlah 28 siswa.

Instrumen dalam penelitian ini adalah 5 butir soal kemampuan komunikasi matematik pada materi segitiga dan segiempat. Dimana kelima soal tersebut telah dilakukan pengujian dan dapat digunakan karena memiliki nilai validitas, realibilitas, daya pembeda, serta tingkat kesukaran yang memadai dengan. Data yang didapat dari hasil pretes dan postes baik kelas eksperimen 
maupun kelas kontrol dilakukan uji n-gain menggunakan rumus $n$-gain ternomalisasi. Sedangkan untuk kategorinya menggunakan interpretasi indeks gain ternormalisasi (g) yang diutarakan oleh Hake (Fauzan, 2018) adalah sebagai berikut:

Tabel 1. Interpretasi $N-$ Gain

\begin{tabular}{cc}
\hline Skor Gain Ternormalisasi & Interpretasi \\
\hline$-1.00<\mathrm{g}<0.00$ & Menurun \\
$\mathrm{g}=0.00$ & Stagnan \\
$0.00<\mathrm{g}<0.30$ & Rendah \\
$0.30<\mathrm{g}<0.70$ & Sedang \\
$0.70<\mathrm{g}<1.00$ & Tinggi \\
\hline
\end{tabular}

Setelah itu data diolah menggunakan software SPSS 20 untuk mengetahui tingkat signifikansi perbedaan peningkatan kemampuan komunikasi matematik antara kelas eksperimen dan kelas kontrol. $\mathrm{H}_{0}$ dalam penelitian ini adalah tidak terdapat perbedaan peningkatan kemampuan komunikasi matematik yang signifikan antara kelas eksperimen dan kelas kontrol.

\section{HASIL DAN PEMBAHASAN}

\section{Hasil}

Berikut ini adalah data hasil pretest dan postest baik kelas eksperimen maupun kelas kontrol.

Tabel 2. Data $N$-Gain Kelas Eksperimen

\begin{tabular}{ccccc}
\hline Kode Siswa & Pretest & Posttest & N-Gain & Kriteria $N$-Gain \\
\hline K1 & 4 & 9 & 0.31 & Sedang \\
K2 & 7 & 11 & 0.3 & Rendah \\
K3 & 3 & 13 & 0.58 & Sedang \\
K4 & 9 & 10 & 0.09 & Rendah \\
K5 & 12 & 13 & 0.13 & Rendah \\
K6 & 7 & 13 & 0.46 & Sedang \\
K7 & 5 & 16 & 0.73 & Tinggi \\
K8 & 5 & 13 & 0.53 & Sedang \\
K9 & 6 & 9 & 0.21 & Rendah \\
K10 & 5 & 13 & 0.53 & Sedang \\
K11 & 6 & 14 & 0.57 & Sedang \\
K12 & 5 & 11 & 0.4 & Sedang \\
K13 & 5 & 11 & 0.4 & Sedang \\
K14 & 7 & 11 & 0.31 & Sedang \\
K15 & 4 & 11 & 0.43 & Sedang \\
K16 & 4 & 12 & 0.5 & Sedang \\
K17 & 10 & 13 & 0.3 & Rendah \\
K18 & 8 & 15 & 0.58 & Sedang \\
K19 & 4 & 16 & 0.75 & Tinggi \\
K20 & 7 & 15 & 0.61 & Sedang \\
K21 & 9 & 17 & 0.72 & Tinggi \\
K22 & 6 & 14 & 0.57 & Sedang \\
K23 & 11 & 14 & 0.33 & Sedang \\
K24 & 4 & 12 & 0.5 & Sedang \\
\hline
\end{tabular}




\begin{tabular}{lllll}
\hline K25 & 5 & 16 & 0.73 & Tinggi \\
K26 & 4 & 13 & 0.56 & Sedang \\
K27 & 6 & 17 & 0.78 & Tinggi \\
K28 & 0 & 16 & 0.8 & Tinggi \\
Rata - rata & N-Gain & 0.49 & Sedang \\
\hline
\end{tabular}

Tabel 3. Data $N$-Gain Kelas Kontrol

\begin{tabular}{ccccc}
\hline Kode Siswa & Pretest & Posttest & N-Gain & Kriteria $\boldsymbol{N}$-Gain \\
\hline K1 & 4 & 7 & 0.18 & Rendah \\
K2 & 4 & 10 & 0.37 & Sedang \\
K3 & 2 & 10 & 0.44 & Sedang \\
K4 & 2 & 7 & 0.27 & Rendah \\
K5 & 8 & 10 & 0.16 & Rendah \\
K6 & 2 & 10 & 0.44 & Sedang \\
K7 & 11 & 15 & 0.44 & Sedang \\
K8 & 6 & 11 & 0.35 & Sedang \\
K9 & 6 & 11 & 0.35 & Sedang \\
K10 & 2 & 9 & 0.38 & Sedang \\
K11 & 6 & 9 & 0.21 & Rendah \\
K12 & 5 & 6 & 0.06 & Rendah \\
K13 & 5 & 10 & 0.33 & Sedang \\
K14 & 5 & 8 & 0.2 & Rendah \\
K15 & 10 & 13 & 0.3 & Rendah \\
K16 & 6 & 9 & 0.21 & Rendah \\
K17 & 7 & 9 & 0.15 & Rendah \\
K18 & 3 & 17 & 0.82 & Tinggi \\
K19 & 3 & 11 & 0.47 & Sedang \\
K20 & 9 & 9 & 0 & Rendah \\
K21 & 8 & 9 & 0.08 & Rendah \\
K22 & 9 & 10 & 0.09 & Rendah \\
K23 & 7 & 11 & 0.31 & Sedang \\
K24 & 8 & 13 & 0.41 & Sedang \\
K25 & 9 & 14 & 0.45 & Sedang \\
K26 & 5 & 12 & 0.46 & Sedang \\
K27 & 7 & 12 & 0.38 & Sedang \\
K28 & 7 & 12 & 0.38 & Sedang \\
Rata - rata & -Gain & 0.31 & Sedang \\
\hline
\end{tabular}

Berdasarkan data $n$-gain ternormalisasi diatas dapat diketahui rata-rata nilai $n$-gain kelas eksperimen adalah sebesar 0.49 dengan intepretasi sedang. Sedangkan rata-rata nilai $n$-gain kelas kontrol adalah sebesar 0.31 dengan intepretasi sedang. Dapat terlihat bahwa kelas yang menggunakan software GeoGebra dalam pembelajaran memiliki nilai peningkatan kemapuan komunikasi matematik lebih baik daripada kelas yang pembelajarannya tanpa menggunakan software GeoGebra. Untuk memastikan bahwa penerapan software GeoGebra dalam pembelajaran dapat meningkatkan kemampuan komunikasi matematik secara signifikan. Maka 
dilakukan uji statistik parametrik data $n$-gain dengan hipotesis jika nilai sig. (1-tailed) $<0,05$ maka $\mathrm{H}_{0}$ ditolak. Hasil pengujian statistika parametrik data $N$-Gain kedua kelas disajikan pada tabel 3 berikut:

Tabel 4 Uji T-Test Data N-Gain

Kemampuan Komunikasi Matematis

\begin{tabular}{cccc}
\hline $\begin{array}{c}\text { Equal } \\
\text { variances } \\
\text { assumed }\end{array}$ & \multicolumn{3}{c}{$\begin{array}{c}\text { Levene's Test for Equality of } \\
\text { Variances }\end{array}$} \\
\cline { 2 - 4 } & $\mathrm{T}$ & Df & Sig. (2-tailed) \\
& 3,636 & 54 & 0,005 \\
& 3,636 & 52,9 & 0,005 \\
\hline
\end{tabular}

Berdasarkan tabel 4 di atas, didapat nilai sig (2-tailed) adalah 0,005. Karena dalam uji hipotesis satu pihak (1-tailed), menurut Uyanto (2009) maka nilai signifikansi $\frac{0,005}{2}=0,0025$. Maka $\mathrm{H}_{0}$ ditolak artinya terdapat perbedaan peningkatan kemampuan komunikasi matematik yang signifikan antara kelas eksperimen dan kelas kontrol.

\section{Pembahasan}

Kemampuan komunikasi matematik merupakan cara siswa untuk mengungkapkan apa yang dia pikirkan, apa yang dia temukan, apa yang dia ingin tanyakan didalam pembelajaran. Hal ini sejalan dengan pernyataan Asikin (2001) bahwa kemampuan komunikasi matematik merupakan suatu dialog antara atau hubungan anatara guru dan murid dalam suatu kelas, sehingga terjaadi pengalihan pesan. Yang dimasud pesan dalam pendapat Askin berupa komunikasi siswa dapat menyampaikan pemikiran, ide, gagasan, dan inisiatif dalam pembelajaran. Selain itu dengan komunikasi siswa dapat menyampaikan mengenai kesulitan kesulitan dalam pembelajaran kepada guru, sehingga guru dapat memberikan umpan balik mengenai kesulitan yang dialami oleh siswa. Kemampuan komunikasi matematik merupakan kemampuan untuk memahami dari suatu konsep materi matematika. Hal ini sejalan dengan apa yang diungkapkan oleh Isaneni \& Ripi Maya (2014) bahwa kemampuan komunikasi matematik berperan sebagai representasi pemahaman siswa terhadap konsep pembelajaran matematika matupun bidang pembelajaran lainnya.

Kemampuan komunikasi matematik merupakan dasar dari seluruh kemampuan kognitif dalam pembelajaran matematik. Hal ini diperkuat oleh pernyataan Ismarwan (2013) bahwa kemampuan komunikasi matematik merupakan dasar kemampuan matematis yang esensial dan harus dimiliki oleh siswa dalam pembelajaran. Karena tanpa kemampuan komunikasi matematik yang baik siswa akan kesulitan untuk menjabarkan data, tabel, membuat pola, membuat model matematika, memahami soal cerita, simbol matematik, grafik, dan konsep konsep matematika. Kemampuan tersebutlah yang dapat menunjuang terbentuknya kemampuan berpikir kritis, logis, sistematis, dan bekerjasama dengan efektif. Hal tersebut akan membentuk cara berpikir matematika yang tersruktur dan memiliki keterkaitan konsep yang kuat dan jelas dan dapat membentuk siswa yang terampil berpikir secara rasional (Depdiknas, 2003). Adapun indikator kemampuan komunikasi matematik menurut NCTM (2000) antara lain sebagai berikut:

1. menyusun pemikiran matematis melalui komunikasi;

2. mengkomunikasikan pemikiran secara logis dan jelas;

3. menganalisis dan mengevaluasi pemikiran matematis dan strategi dalam pembelajaran; 
4. menggunakan bahasa matematis untuk menyampaikan ide dengan tepat.

Menurut Zavenbergef, Dole, \& Wrigh (2004) ada lima bentuk komunikasi dalam pembelajaran matematika antara lain sebagai berikut:

1. komunikasi lisan, yaitu komunikasi berupa diskusi antara siswa dengan siswa maupun siswa dengan guru dalam kegiatan pembelajaran;

2. komunikasi visual, yaitu pemodelan yang dilakukan oleh guru misalnya berupa bangun 2 dimensi maupun 3 dimensi dalam suatu pembelajaran bangun datar dan bangun ruang;

3. komunikasi digital, yaitu komunikasi pembelajaran menggunakan teknologi komputer;

4. komunikasi tertulis, dapat berupa penjelasan mengetai definisi suatu materi, dugaan, dan lain-lain;

5. komunikasi simbolik, yaitu komunikasi menggunakan simbol-simbol yang ada dalam pelajaran matematika.

Berdasarkan lima bentuk komunikasi dalam pembelajaran yang diungkapkan oleh Zavenbergef, Dole, \& Wrigh diatas maka dapat diketahui hal yang mendasari terjadi perbedaan peningkatan signifikan antara kelas ekperimen yaitu kelas yang pembelajarannya menggunakan software GeoGebra dan kelas kontrol yaitu kelas yang pembelajarannya tanpa menggunakan software GeoGebra. Dimana pembelajaran yang menggunakan software GeoGebra akan membantu guru memunculkan bentuk komunikasi visual. Hal ini dikarenakan dengan software GeoGebra guru dapat menampilkan visual baik 2 dimensi maupun 3 dimensi dengan cara menarik. Hal ini sejalan dengan pendapat Hohenwarter (2008) bahwa GeoGebra adalah program dinamis yang dengan beragam fasilitasnya dapat dimanfaatkan sebagai media pembelajaran matematika yang digunakan untuk mendemonstrasikan atau memvisualisasikan konsep-konsep matematis serta sebagai alat bantu untuk mengkonstruksi konsep-konsep matematis. Dengan software GeoGebra siswa dapat memami konsep matematika dimanapun dan kapanpun sehingga mempermudah siswa untuk meningkatkan kemampuan komunikasi matematk disetiap harinya. Hal ini sejalan dengan yang diungkapkan oleh Munir (2010) bahwa software GeoGebra merupakan implementasi pembelajaran yang menggunakan teknologi dan tidak terbatas ruang dan waktu. Selanjutnya adalah pembelajaran yang menggunakan software GeoGebra akan membantu guru memunculkan bentuk komunikasi digital.

Dengan menggunakan software GeoGebra itu berarti seorang guru dapat memberikan komunikasi digital dalam kegiatan pembelajaran. Sehingga guru dapat mengimplementasikan pembelajaran berdasarkan Kurikulum 2013 dimana seorang guru harus menggunakan TIK sebagai media dan alat bantu dalam kegiatan pembelajaran. Hal ini sejalan dengan apa yang diungkapkan oleh Ngurah Japa (2017) bahwa dengan adanya TIK dapat memberikan nuansa baru dalam kegatan pembelajaran. Nuansa disini dapat dinyatakan sebagai pengimplementasian bentuk komunikasi visual dan digital dalam pembelajaran matematika. Penulis juga mengamati secara langsung bahwa dengan bantuan software GeoGebra dalam pembelajaran siswa menjadi lebih aktif dalam pembelajaran. Dimana siswa jadi lebih sering bertanya, mengungkapkan ide dan pendapat dalam kegiatan pembelajaran. Hasil penelitian diatas sejalan dengan peneltian yang dilakukan oleh Dian yang dilakukan di sebuah SMP Negeri di Lembang, dengan judul penelitian "Penerapan Pembelajaran Matematika Realistic Berbantuan GeoGebra untuk Meningkatkan Kemampuan Komunikasi Matematis Siswa SMP." 


\section{KESIMPULAN}

Berdasarkan data hasil penelitian dan uraian pembahasan diatas maka dapat disimpulkan bahwa penerapan software GeoGebra dalam pembelajaran matematika SMP kelas VIII di SMP Pasundan Rongga dapat meningkatkan kemampuan komunikasi matematik siswa. Kesimpulan tersbut didapat dengan melihat baik skor $N$ - Gain ternormalisasi maupun uju statistika parametrik yang menunjukan perbedaan yang signifikan dimana kelas yang menggunakan pembelajarannya menggunakan software GeoGebra lebih baik daripada kelas yang menggunakan pembelajarannya tanpa menggunakan software GeoGebra. Kemampuan komunikasi matematik siswa juga ditunjukkan berdasarkan observasi bahwa dengan menggunakan software GeoGebra dalam pembelajaran siswa menjadi lebih aktif dalam pembelajaran. Dimana siswa jadi lebih sering bertanya, mengungkapkan ide dan pendapat dalam kegiatan pembelajaran.

\section{DAFTAR PUSTAKA}

Depdiknas. (2003). Kumpulan Pedoman Kurikulum 2004. Jakarta: Depdiknas.

Fauzan, GA., Aripin U. (2018). Jurnal Pendidikan Matematika Inovatif. Penerapan Ice Breaking dalam Pembelajaran Matematika untuk Meningkatkan Rasa Percaya Diri Siswa Kelas VIII B SMP Bina Harapan Bangsa. Diakses dari http:// journal.ikipsiliwangi.ac.id

Japa, N., Suarjana., \& Widiana. (2017). International Journal of Natural Science and Enginering. Media GeoGebra dalam Pembelajaran Matematika. Diakses dari http:// eajournals.org

Hohenwarter, J., \& Hohenwarter, M. (2008). Introduction to GeoGebra (written for GeoGebra 3.0). Tersedia: http://docplayer.info/96840

Kemendikbud. (2013). Kerangka Dasar dan Struktur Kurikulum 2013. Jakarta: Kemendikbud

Khadijah, I.N.A., Maya, R., Setiawan, W. (2018). Jurnal Pendidikan Matematika Inovatif. Analisis Kemampuan Komunikasi Matematis Siswa SMP pada Materi Statistika. Diakses dari http:// journal.ikipsiliwangi.ac.id

Munir. (2010). Kurikulum Berbasis Teknologi dan Komunikasi. Bandung: Alfabeta.

NCTM. (2000). Principles and Standards for School Mathemarics. Reston: NCTM.

Permendikbud. (2013). Penilaian Hasil Belajar oleh Penidikan pada Pendidikan Dasar dan Pendidikan Menengah. Jakarta: Kemendikbud.

Uyanto, S. (2009). Pedoman Analisis Data dengan SPSS. Yogyakarta: Graha Ilmu.

Zevenbergerf, J. R., Dole, S., \&Wright, R. J. (2004). Teaching Mathematics in Primary Schools. New South Wales: Allen \& Unwin.

Yuliani, SR., Setiawan, W., Herdiana H. (2019) Jurnal Pendidikan Matematika Inovatif. Analisis Kesalahan Siswa SMP pada Materi Perbandingan Ditinjau dari Indikator Kemampuan Pemecahan Masalah Matematis. Diakses dari http:// journal.ikipsiliwangi.ac.id 